\title{
Effective Communication for Improving Local Tourism in West Java
}

\author{
B Tresnawaty ${ }^{1}$, Dyah Rahmi Astuti ${ }^{2}$ \\ UIN Sunan Gunung Djati, Bandung, Indonesia ${ }^{1,2}$ \\ \{betty.tresnawaty@uinsgd.ac.id $\left.{ }^{1}\right\}$
}

\begin{abstract}
The competition between industries or companies engaged in the service sector has been increased, which is the front line of a company, it is needed to build the ability to communicate are qualified to improve the quality of service, based on the effective communication theory. West Java is one of the provinces in Indonesia which has a wide range of cultural values of local wisdom sublime. The value of local wisdom can be used as a foundation to build a unique form of interpersonal communication that is typical of West Java, especially in terms of interpersonal communication. This study used an interpretive paradigm (subjective) through constructivist methods Phenomenology. Symbolic interaction theory and phenomenology of Alfred Schutz will be used to explore the phenomenon in this study. The purpose of this study aims to explore and analyse the values of local wisdom in improving communication competences, and develop a service concept that is characterized by typical West Java. Based on the research, found a Hospitality Communication concept is lifted from the values of local wisdom of West Java. This concept can be used as a model in business competition, especially to enhance the tourism industry in West Java.
\end{abstract}

Keywords: Communication Competence, Local Wisdom, Hospitality Communication

\section{Introduction}

Indonesia is a nation with a rich culture and tradition of good service but already much forgotten, but can be the basis for winning a business competition, especially in the tourism business. Similarly, in West Java, which has a wide range of local cultures, especially cultures that vary depending on the area of Sundanese. Some places that I visited to explore the values of local wisdom are Garut, Tasikmalaya, Bandung, and Sukabumi. West Java has a diverse culture and beautiful natural conditions, which became one of the destinations of local and foreign countries.

This triggers the emergence of tourist businesses in West Java, such as hotels, restaurants, entertainment venues, special events, and others. These conditions encourage the businessmen of tourism to improve the quality of human resources, and the most important is the quality of 
the ability to communicate with others, consumers and customers. Complaints from consumers and customers is the great enemy in the tourism business, especially in this era of communication technology, where every consumer interconnected with social media. The power of social media by a few media studies research has informed how powerful the effect of social media to influence public perception. Assessment of the community is very concerned with image formation of companies in the tourist field, will indirectly affect the number of consumers and customers who come.

Every organization wants a good reputation, a good reputation can be achieved by the formation of a positive image. The management of a positive image is the duty of every employee in the company, especially those directly related to the consumer, such as front desk, maids, and public relations officer. Referring to the concept of interpersonal communication have different definitions of some communications experts, perhaps should be defined in the broadest sense to include all interactions where there is a relationship between all participants [1].

Then hospitality communication included in the study of interpersonal communication, because somehow in communicating with others, in this case, the tourists who come, will always involve an element of interpersonal relationships. The tourists will feel communicate with the public or if treated with care officer familiar. Based on the above background, the purpose of this study are:

- To explore and analyze the values of local wisdom in improving communication competences

- To develop a concept of service characterized by typical West Java

\section{Literature review}

Some of the previous research become the foundation of this research. One of them is Hospitality Communication [2]. So this is a continuation of the research.A few thoughts of the experts are used as references to analyze our research findings; they are phenomenological theory and symbolic interaction theory.

\subsection{Phenomenological Theory of Alfred Schutz}

Thought of Alfred Schutz in his book titled "The Phenomenology of The Social World", as described George Walsh in [3], Schutz become interested quite early in the work of the greatest of German sociologist, Max Weber, especially in the latter's attempt to establish a consistent methodological foundation for the social sciences. For Schutz, and understanding of the phenomenological, the main task is to reconstruct the world of phenomenological analysis of human life "is actually" in the form of their own experience. The reality of that world is intersubjective in the sense that community members share a basic perception about the world that they are internalized through socialization and allows their interaction or communication.

\subsection{Symbolic Interaction Theory}

According to Weber, not all human action is referred to as social action. An action can only be called a social action if social action by considering the behavior of others and oriented to the behaviour of others. So the social action is human behavior that has a subjective meaning to his behaviour [3]. In this perspective the individual is active, reflective, 
and creative, interpreting, displaying the behavior of complex and difficult to predict. Got it rejects the notion that the individual is an organism whose behaviour is determined by passive forces or structures that exist outside him. Therefore the individual is constantly changing so the society changed through interaction. So the interactions are considered important variables that determine human behavior, not the structure of society. The structure itself is created and changed due to human interaction when individuals think and act in a stable to the same set of objects [4]. Symbolic interaction perspective of trying to understand human behavior from the viewpoint of the subject. This perspective suggests that human behaviour should be seen as a process that allows humans to form and regulate their behaviour by considering the expectations of others who become their interaction partners. The definition they give to others, situations, objects, and even their self that determines their behavior. Their behavior cannot be classified to the needs, drives the impulse, cultural demands, or demands of the role. Man acts only based on their interpretation of the definition or the objects around them.

\section{Methods}

Thought of phenomenological is not only the philosophy but the theory and method as well Development of phenomenological method leads to the focusing of attention to the phenomena without preconceptions. The process is the famous phrase sachenzu den Selbst (directed to the object itself). In this focusing to it, in fact, the reality is allowed to disclose the nature itself. The real nature of the phenomenon behind the appearance. The first observation is not necessarily able to make it reveal the nature of the phenomenon itself. Hence, it needs a second observation is referred to as intuitive observation. We observed four places in West Java: Garut, Tasikmalaya, Bandung, and Sukabumi. The informants of this research are hotel maids, restaurant waiters, some persons who work in tourism industries, and also people who stay in those traditional villages.

\section{Results and discussion}

Based on observations to areas in West Java, especially Garut, Tasikmalaya, Bandung and Sukabumi, as well as interviews with the people of West Java especially the customary figures, I find things that are incredible escape my attention during this time. I used to be guided by the theories of communication from abroad as my academic references, but apparently my region, namely West Java has the concept of a genuine communication from the Sundanese region.

Once we observed and learned, it turns out that when the concepts more deeply understood, then it is a communication concept that is purely from the Sundanese region which implies a noble and sacred. It is the local wisdom of the area of the Sundanese based science communication. The concept of communication is more likely to form interpersonal communication. It turns Sundanese people have always had a way of interpersonal communication that is appropriate and effective. Forms of symbols and local wisdom are maintained by the community of Kampung Pulo, Kampung Naga, and Kasepuhan Cipta gelar which used to communicate in preserving and simultaneously convey a concept system at their disposal, as well as the identity of the cultural community of Kampung Pulo, Kampung Naga, and Kasepuhan Cipta gelar are very likely done by them, because culture is basically a pattern tangible meaning in symbolic forms.

The concept is, unfortunately, many left by the Sundanese community itself, whereas if associated with the concept of communication of these values is the concept that the original 
communication from the West Java region, and this is a very effective communication concept for Interpersonal communication forms. According to Steward L. Tubbs and Sylvia Moss, cited by Jalaluddin Rahmat [5], effective communication led to at least five areas:

- Understanding, acceptance careful of the stimuli contents as it was intended by the speakers, in this case the receipts careful of the message content that is intended by the employees or officer services to the visitors,

- Comfort, basically the communication is not just to deliver information only and establish mutual understanding, but communication is also intended to have warmth in the interaction with the information or message please others, to do with the company in the field of tourism businesses, which has the ability to convey information to the visitors may lead to a sense of comfort and safety

- Influencing attitudes, primary domain communication process actually is influenced the attitude of others, to be able to influence others, we need a psychological approach in the form of emotional appeals, this can be done if the communication did psychological approach, in this case those employees or service personnel should consider aspects psychologically attached to the community as the recipient of the message so that it can affect their attitude to behave according to what is expected without feeling forced

- The good social relations, communication is aimed at creation of social relationships are nurtured well. In the context of inclusion it is necessary to reinforce the communication for the company and community relations. In the context of the establishment of control then control each other between the company and the community through communication. Meanwhile, in the context of the affection that wants to be loved and to love the absolute need for communication to those needs can be revealed,

- Actions, influence others can succeed if the visitors take action as what is desired and this is the last indicator in addition to the four items described above. Action is the accumulation of the communication process and this requires knowledge of the mechanism of psychological factors that affect one's actions, in this case the expertise of employees in communication capable of influencing people to take real action. In the case of the tourism business, the first acts of tangible actions could include buying behaviour and choosing hotels, restaurants, and tourist attractions specific to their liking.

Other factors that influence effective communication, the choice of vocabulary or language used, as it relates to the value of a sense of language or vocabulary we choose to convey information, in this case the service officer or employee of a company must be clever in choosing words that are appropriate for specific situations in a variety of community character. In addition nonverbal messages also must be considered and adapted to the words spoken so further strengthen and support the verbal messages. Nonverbal messages, namely the movement of limbs, facial expressions, gestures, and appearance. Indeed nonverbal message that is consistent with the verbal message is a natural fit for granted what is in the heart, for that is a factor in good faith and our conscience will be reflected in facial expressions and body movements. This is when applied to communicate with anyone, in this case on the tourists who came, it will make the tourist business forward. Human resources who have good communication skills that humans have the ability hospitality communication is high, then the ultimate goal of any communication process, effective communication, will be achieved 
perfectly. The attitude of the hotel maid varied depending on the self-concept which is owned by the respective hotel maid. Friendly and courteous attitude certainly can provide value to consumers / customers. Having a friendly attitude and manners is not easy. For those who do not have hospitality and wholeheartedly course will feel tired and miserable only owned by people who have a positive self-concept. The self-concept is a way of looking ourselves as what is and what our feelings and perspectives of others to ourselves will affect the pattern of our interactions with others.

Analysis of consumers meant that the waiter can understand the desires and expectations of guests so that consumers/customers felt comfortable, safe and satisfied with the services and facilities provided by the hotel company. Consumer analysis conducted by collecting data/fact finding and one of the ways of data collection can be done through a survey of consumer/customer, consumer surveys can be done at the end of the visit hotel guests. Consumers/customers are given the freedom to criticize, give feedback/suggestions on the services and facilities of the hotel. The survey shows that consumers expect the attention of the hotel maid, although just say the name let alone to remember the consumer will feel happy, cared for and appreciated, consider the quality of the food in the restaurant, manner of presentation, taste quality, cleanliness of utensils. The results of the analysis shows that should the hotel in advance to try the food/beverages will be served to hotel guests in order to maintain standards of the hotel or restaurant. A Good service is supported with a good attitude. Attitude is one important element in the process of service. Sunda famous someah, friendliness owned Sunda also need to be owned by the hotel maid who develop Sundanese culture through the concept of his hotel in order to establish good interpersonal relationships, so that interpersonal communication is done giving birth effective interpersonal relationships, then you should communicators can build a sense of trust, supportive attitude and an open attitude that the emergence of mutual understanding, mutual respect and most importantly, both developing interpersonal relationships with good quality.

\section{Conclusion}

Based on the analysis, the authors concluded that the hotel is characterized by a culture of service needs to pay attention to the hotel staff in communicating both verbally and nonverbally. The hotel employers were in direct contact with consumers should understand some of the issues related to interpersonal communication in interpersonal relationships in order to maintain customer loyalty:

- Some things to note for the hotel staff that has a positive self-concept, self-presentation as a representation of the hotel which has a characteristic Sundanese culture, consumer analysis in order to understand the desires and expectations of consumers, an attitude reflecting Sundanese culture and human relations and the following description of Concept

- Application of Communication competence aims to attract tourists to visit because of the appeal of the uniqueness of the concept of hospitality West Java. Application of communication in the business world hospitality tourism in West Java, can be done through a special communication competences training to apply the concept of hospitality communication, given to employees and all parties involved in the tourism business. 
The concept of training by applying the values of local wisdom that I have discovered from the results of this study, so useful for enhancing the service quality of service personnel, and become equipped to deal with the character of the consumer/customer in a way that is friendly, professional, and proportionate. Application of hospitality communication could be one solution to improve the quality of service, in the language of the service is to provide excellent service, then become costumers loyalty.

\section{References}

[1] J. A. Devito, Komunikasi Antar Manusia: Kuliah Dasar Edisi Kelima, vol. 5. Jakarta: Proffesional Books, 1997.

[2] B. Tresnawaty, "Hospitality Communication: A Phenomenological Study based on Local Wisdom of West Java," Pertanika J. Soc. Sci. Humanit., vol. 24, pp. 225-32, 2016.

[3] Kuswarno, Metodologi Penelitian Komunikasi: Fenomenologi Konsepsi, Pedoman dan Contoh Penelitian. Bandung: Widya Padjajaran, 2009.

[4] D. Mulyana, Ilmu Komunikasi: Suatu Pengantar. Bandung: PT Remaja Rosdakarya, 2003.

[5] J. Rakhmat, Psikologi Komunikasi. Bandung: PT Remaja Rosdakarya, 1991. 